UDC 330

DOI: 10.31891/2307-5740-2021-300-6-40

WLADYSLAW WORNALKIEWICZ

e-mail: wornalkiewicz@wp.pl

The Academy of Management and Administration in Opole, Poland

YURII KRAVCHYK

ORCID ID: 0000-0002-2780-5605 e-mail: gromplus7@gmail.com

Khmelnytskyi National University

OLENA PADCHENKO

Zaporizhia Polytechnic National University ORCID ID: 0000-0002-5262-2755

E-mail: padchenkolena@ukr.net

\title{
INFORMATION SUPPORT OF THE LONG CARGO FORWARDING SYSTEM
}

This paper provides a short overview of the systems supporting the TDL industries (Transportation, Distribution, \& Logistics) available on the market. The software was considered in terms of its suitability for companies specializing in the transport of oversized long cargo. The programs mentioned in the work do not constitute a closed directory. When choosing the systems, their popularity and availability were taken into account. Programs supporting TDL industries can be grouped into three basic categories, such as: freight exchanges, fleet management systems, and specialized software. An employee of an exemplary logistics company was asked about the usefulness of these systems in a company that transports oversized long cargo. The example of an interview conducted in an example logistics company was used to present which IT applications are currently used. The interview with the respondent revealed significant shortcomings in the specialist software market. The collected information indicates the need to build an integrated logistic IT system for the industry dealing with comprehensive delivery from the producer to the place of assembly of long and often heavy, uniform long structures.

Keywords: oversized transport, long cargo, logistics systems, software.

ВОРНАЛКЕВІЧ В.

Академія управління і адміністрації в Ополе, Польща КРАВЧИК Ю. В.

Хмельницький національний університет ПАДЧЕНКО О. О.

Національний університет «Запорізька політехніка»

\section{ІНФОРМАЦЙНЕ ЗАБЕЗПЕЧЕННЯ СИСТЕМИ ЕКСПЕДИЦІї ВЕЛИКОГАБАРИТНИХ ВАНТАЖІВ}

У цій статті наведено короткий огляд доступних ринку систем, що підтримують галузі TDL (транспорт, дистрибуція та логістика). Програмне забезпечення було розглянуто з точки зору його придатності для компаній, що спеціалізуються на перевезенні великогабаритних довгомірних вантажів. Програми, згадані в роботі, не $\epsilon$ закритим довідником. При виборі систем враховувалися їх популярність і доступність. Програми, що підтримують галузі TDL, можна згрупувати в три основні категорії, наприклад: біржі вантажів, системи управління автопарком та спеціалізоване програмне забезпечення. Співробітника зразкової логістичної компанії запитали про корисність цих систем у компанії, яка перевозить великогабаритні вантажі. На прикладі інтерв'ю, проведеного в прикладі логістичної компанії, було показано, які IT-додатки зараз використовуються. Інтерв'ю з респондентом виявило суттєві недоліки ринку спеціалізованого програмного забезпечення. Зібрана інформація вказує на необхідність побудови інтегрованої логістичної IT-системи для галузі, що займається комплексною доставкою від виробника до місця монтажу довгих і часто важких, однорідних довгомірних конструкцій.

Ключові слова: негабаритний транспорт, великогабаритні вантажі, логістичні системи, програмне забезпечення.

\section{Introduction}

Currently, in the aforementioned enterprises, several systems are used simultaneously. There is no single IT tool supporting the activity in the field of freight forwarding and transport of debt, which would contain all the most important and most desirable functions. Additionally, deficiencies in the digitization of administrative procedures related to irregular journeys were indicated. The methods of obtaining permits for travel in Western European countries, which are based on filling in a form via websites, were presented. The issue of the road database, which is successfully operating in most European Union countries, was mentioned. The aforementioned database not only contains information on the individual dimensions of the road but also determines the optimal route itself, taking into account the declared parameters of the vehicle and the condition of the infrastructure.

\section{Analysis of research and publications}

The work of Ukrainian and foreign researchers was devoted to information support of the long cargo forwarding system (O. Chukurna [1, 2], N. Havrylenko [3], T. Nestorenko [8, 9], A. Ostenda [11], Wornalkiewicz W. \& Kravchyk Yu. [17], T. Zubro [18]). The transport of oversized cargo is received so much attention from foreign scholars, such as Z. Jóźwiak [5], D. Marciniak-Neider D. \& J. Neider [6], Sosnowski J. \& Nowakowski Ł. [11], and others. 
The main purpose of the article is to study information support of the long cargo forwarding system.

Presentation of the main research material. Possibilities of improving the IT applications used to support the transport of long cargo are presented on the example of the operation of the company Transport Towarowy Waldemar Kurspiot (TTWK) in Podgórna near Głogówek and as a result of an interview with its employee. Special attention was paid to the specialized logistics and forwarding software available on the market, the most popular programs were selected and their functionality was analysed. In addition, examples of virtual transport exchanges, fleet management systems based on GPS technology, and specialized systems for calculating axle loads of nonstandard vehicles were discussed. As a result of the interview, the realities of using these systems in a company from the TSL industry (Transport-Forwarding-Logistics) were presented. However, the main goal of the study was to answer the question about the demand for comprehensive specialized software for companies dealing in oversized transport, and above all, to extend the length. The view of the home page of this company is presented in Fig. 1.

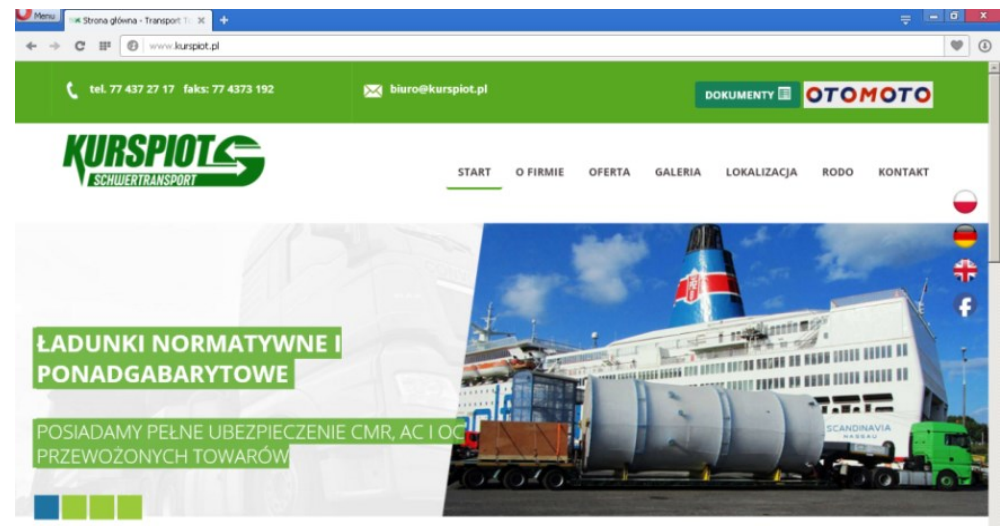

Fig. 1. Company home page Transport Towarowy Waldemar Kurspiot (TTWK) Source: http://www.kurspiot.pl

\section{Long cargo organization}

Routing is the basic task of the oversized cargo transport organizer and is one of the main conditions for obtaining a permit. The roads are adapted primarily to the traffic of standard vehicles, therefore the presence of viaducts, footbridges, road tunnels, or nearby buildings is considerable difficulty in planning the route. The bridge structures over the road are designed to allow vehicles up to $4.0 \mathrm{~m}$ high to pass. The arches at intersections and roundabouts are profiled so that vehicles up to $18.75 \mathrm{~m}$ can pass freely on them, and the road surfaces and engineering structures are designed for a maximum of 40-tonne sets [7]. Obstacles are an additional problem: objects located in the road lane. Obtaining permission to travel must be preceded by a detour of the typical route, and the transport of goods must be considered individually on a case-by-case basis. When planning the route of nonstandard transport, it is necessary to take into account [6]:

- extremely vertical and horizontal roadways (free space above and next to the road, with dimensions depending on the class and type of road), the height of viaducts, the presence of traffic lights, overhead lines, railway lines, etc.;

- strength of the structure of bridges and viaducts and the need to commission costly expert opinions in this area;

- the necessity to find car parks and parking spaces to perform legally prescribed breaks in driving (stop from 6:00 to 22:00);

- the need to temporarily suspend driving in connection with the need to dismantle infrastructure devices, and to prepare the route in places where road works are carried out.

However, more and more often it can be noticed that the newly remaining road sections and the modernization of the existing ones take into account the journeys of non-standard transports. A good example is the construction of turbine roundabouts (two or several lanes) and the construction of large-diameter roundabouts, the shield of which has an undeveloped surface intended for straight-ahead driving, which greatly facilitates the transport of long logs whose parameters (length) make it impossible to drive around the roundabout in a circular manner (Fig. 2).

Another example of adapting the infrastructure to non-standard transport delivery is the structural reinforcement of road culverts and the widening of the roadway. Nevertheless, the current condition of public roads and their geometry is still a significant challenge when planning the course of non-normative transport.

The pilotage of the journey is an important and characteristic element of non-standard transports. It was indicated in the aforementioned Regulation of the Minister of Transport, Construction, and Maritime Economy on piloting non-standard vehicles. Piloting is an activity performed by a person authorized to pilot, driving a vehicle adapted for this purpose, the task of which is to secure road traffic during non-normative journeys [14]. The role of the pilot is to directly supervise and ensure the proper organization of the passage of vehicles so that it takes place in accordance with the conditions contained in the permit. The pilot is entitled to control road traffic (e. g. stopping 
traffic on a bridge) so that the passage does not cause any danger to infrastructure elements and other road users. The pilot is also the decision-making person in terms of the need to stop the journey, in the event that new circumstances may drastically reduce road safety during the journey.

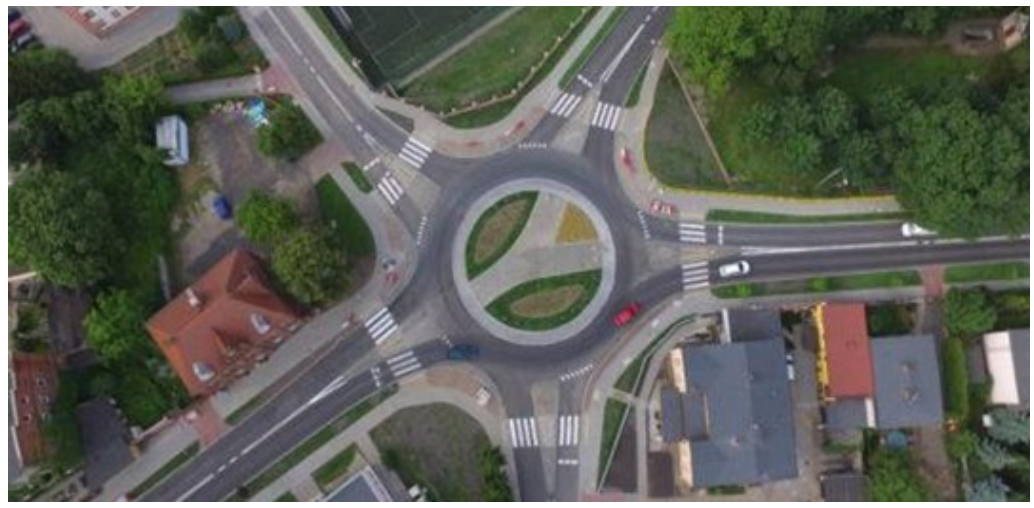

Fig. 2. The intersection is adapted to non-standard transports

Source: http://kcynia.info/kategoria/rondoinformator/

A pilot vehicle is a vehicle whose mass does not exceed 3.5 tons and is marked with a white reflective information "PILOT" on the roof, containing information about the largest parameter of the width of the piloted vehicle. In addition, the vehicle is equipped with 2 yellow flashing lights, located on the roof, which provide visibility from a distance of $150 \mathrm{~m}$, from all sides of the vehicle, but do not cause glare. This is to warn other road users of impending traffic obstruction. An important element of the pilot vehicle's equipment is the elements of direct communication with the vehicle that carries out the transport of oversized cargo and the sound system. An oversized vehicle requires piloting if the following values are exceeded:

- length: $23 \mathrm{~m}$,

- width: $3.20 \mathrm{~m}$,

- height: $4.50 \mathrm{~m}$

- total weight: 60 ton.

If the length exceeds $30 \mathrm{~m}$, the width is $3.6 \mathrm{~m}$, the height is 4.70 , and the total weight of the vehicle is 80 tons, then such transport requires the intervention of two pilots who secure the vehicle at the front and rear.

As already mentioned, the $\log$ is, by definition, round large-size timber with a length of at least $6 \mathrm{~m}$. In practice, logs are loads of non-standard transports, the permissible length of the set exceeds $16.5 \mathrm{~m}$. These are most often composite (indivisible) elements of bridge structures (bridge spans, railings, pillars, reactors, columns), installations for refineries and elements of wind farms. There are about 10 leading companies in Poland that specialize in the production of bridges: POLIMEX-MOSTOSTAL (produces elements with a length equal to or not exceeding $30 \mathrm{~m}$ ), KONSTALEX RADOMSKO (produces loads equal to or exceeding $40 \mathrm{~m}$ ), and MOSTOSTAL KIELCE, (produces products reach a length of up to $35 \mathrm{~m}$ ) [5].

It should also be noted that the places of production of complete objects and their modules do not coincide with the places of their final installation, an example of which are "wind farms", most often located in inaccessible places, remote from human habitats, with an undeveloped network of roads or their complete absence. An equally important aspect is the high level of specialization of companies producing windmills, which means that their elements are produced in companies located in different parts of the world, which forces them to be transported to the assembly site. Wind farms are produced all over the world, which is related to the growing trend of obtaining energy from renewable sources. One of the largest producers is the Danish company VESTAS, which sells elements of wind farm structures to 70 countries [5]. The basic elements of wind turbines (power plants), for which it is necessary to use non-standard transport each time, include practically all its elements [5], such as towers, nacelles, and rotors with blades, with the dimensions shown in Table 1 [5].

Table 1

Dimensions of construction modules of wind farms

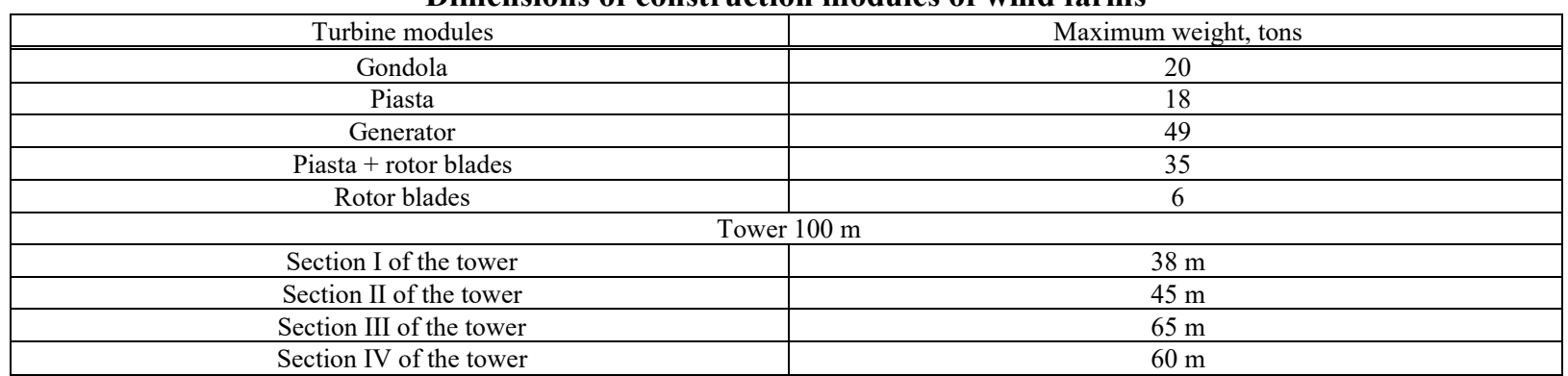


The data in the table 1 shows that the individual modules of the wind power plant weigh from 6 to 49 tons. Individual sections of the tower, which are up to $60 \mathrm{~m}$ long. Analyzing the above table, it can be clearly stated that the transport of power plant modules cannot take place without the participation of normative transport, because the elements listed in the table are indivisible loads.

Depending on the dimensions of the transported windmill parts, it is required to use appropriate and specialized semi-trailers. For transporting tower sections, Tele and MegaTele stretch trailers are used, which are adapted to transport loads up to $36 \mathrm{~m}$ long. Modular trailers are also used, consisting of two hydraulic parts that form the so-called adapter for supporting the load on both sides (the so-called Lift Adapter). Thanks to the use of such semi-trailers for transporting logs, it is possible to turn the axles up to $80^{\circ}$, which helps to overcome horizontal curves with small angles of curves [15].

Long-term semi-trailers can be additionally equipped with actuators enabling the lifting of the transported elements to a height of up to $2.2 \mathrm{~m}$ above the road, which helps in negotiating bends and intersections with circular traffic. When transporting to mountain areas, forests, or tightly built-up towns, lifting the load is the only alternative solution for logging trees and reconstructing entire intersections.

\section{Computer support for the forwarding oversized cargo}

Virtual transport exchanges, also known as freight and cargo space exchanges, are innovative online platforms whose task is to enable the TDL sectors to perform activities such as searching for freight and searching for free cargo spaces, which significantly improves the performance of logistics processes, thanks to which enterprises strengthen their position among competitive companies. Transport exchanges currently operating on the market have the function of expressing opinions and recommendations about transport and forwarding companies and the function of authorizing new entities appearing on the platform, which is a tool to ensure safe use. Transport exchanges also include online user forums, thematic panels on news in the TDL industry, news in the field of transport law, and issues supporting broadly understood business activity.

A Polish example of a well-functioning freight exchange platform is the TRANS.EU system, which appeared on the market in 2004. Over 200,000 users from 45 European countries publish and search for loads and vehicles every day. The TransRisk function estimates the risk of entering into a contract between entities, guided by the assessments of the companies concerned [12]. The TRANS.EU system also allows you to generate transport orders concluded via the platform, using the TransOrders function. This system also provides its users with several other additions, namely:

- Trans.Info - a virtual database of information on the transport business in the form of sharing the latest information in the TDL industry;

- A base of free guides and the possibility of exchanging experiences on thematic forums;

- Translnkasso - an additional factoring service;

- TransBrokers - an additional service for concluding favorable insurance for transport companies operating on the exchange in question.

The entrance to the website of the TRANS.EU system is shown in Fig. 3.

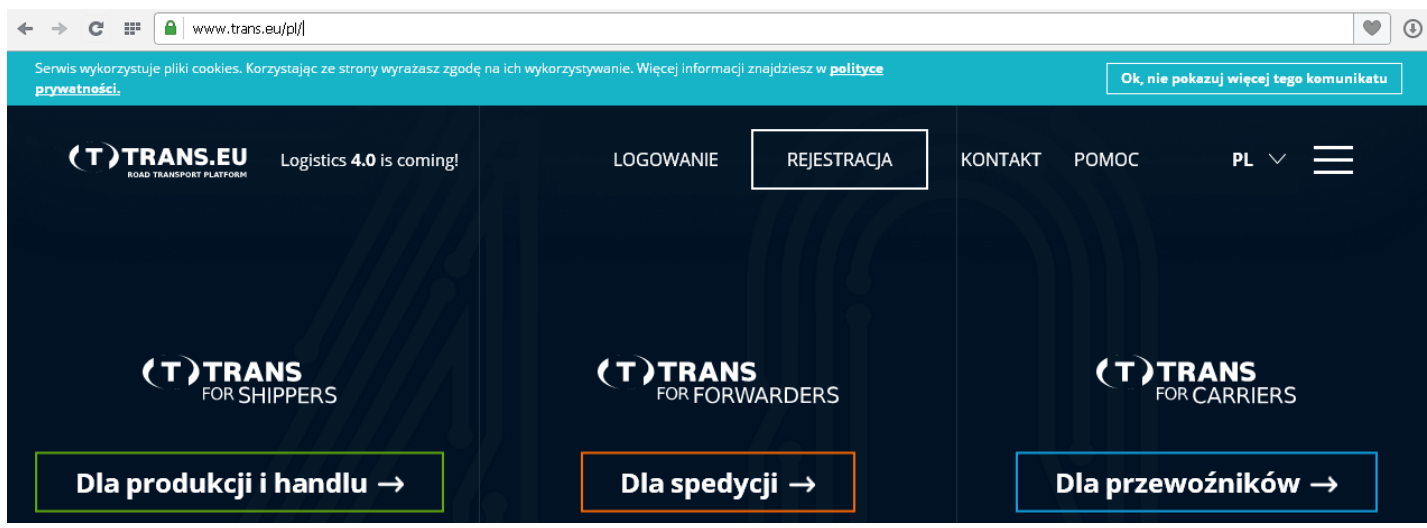

Source: $\underline{\text { https://www.trans.eu/pl//) }}$

Fig. 3. System home page TRANS.EU

The TimoCom service is another example of a virtual freight exchange, and a company that has been operating on the market for more than 6 months can join it. The authorization process includes, among others [12]:

- detailed inspection of documents relating to the company's operations, i.e. the National Court Register

(Krajowy Rejestr Sadowy - KRS), licenses held);

- confirmation of financial condition;

- verification in the debtors database;

- analysis of potential capital and personal links with other entities. 
According to https://cutt.ly/RWfoP6K, TimoCom also offers the route calculation module service, which calculates and plans routes directly from the transport offer [4], and the option of tracking, i.e. observing the movement of transport in real time (Fig. 4).

The Transport Fleet Management System is a solution for monitoring and protection of vehicles, drivers and transported loads. It is a tool supporting fleet management and optimization of its use as well as control of transport processes carried out in the company [13]. The fleet management system is based on GPS, i.e. the global positioning system, operating since 1983, and GPS in road transport enables [13]:

- determining the location of the vehicle,

- control supervision of the cargo or the contents of the container,

- supervision of dangerous goods,

- protection against theft of the vehicle: blocking the vehicle when parked.

The main advantage of the GPS is the provision of an interactive map that facilitates route planning and shows traffic situations in real-time, thanks to which the driver can choose an alternative route. From the point of view of transport activities, GPS is the main element of the company's fleet monitoring, but to obtain useful information, apart from installing a GPS receiver, you should also have a GSM transmitter, a system of servers collecting information, and a client's application (software) that allows you to track the route of the vehicle in realtime [7]. There are many telemetry applications on the market that differ in the appearance of the application interface, price, and dedicated recipients.

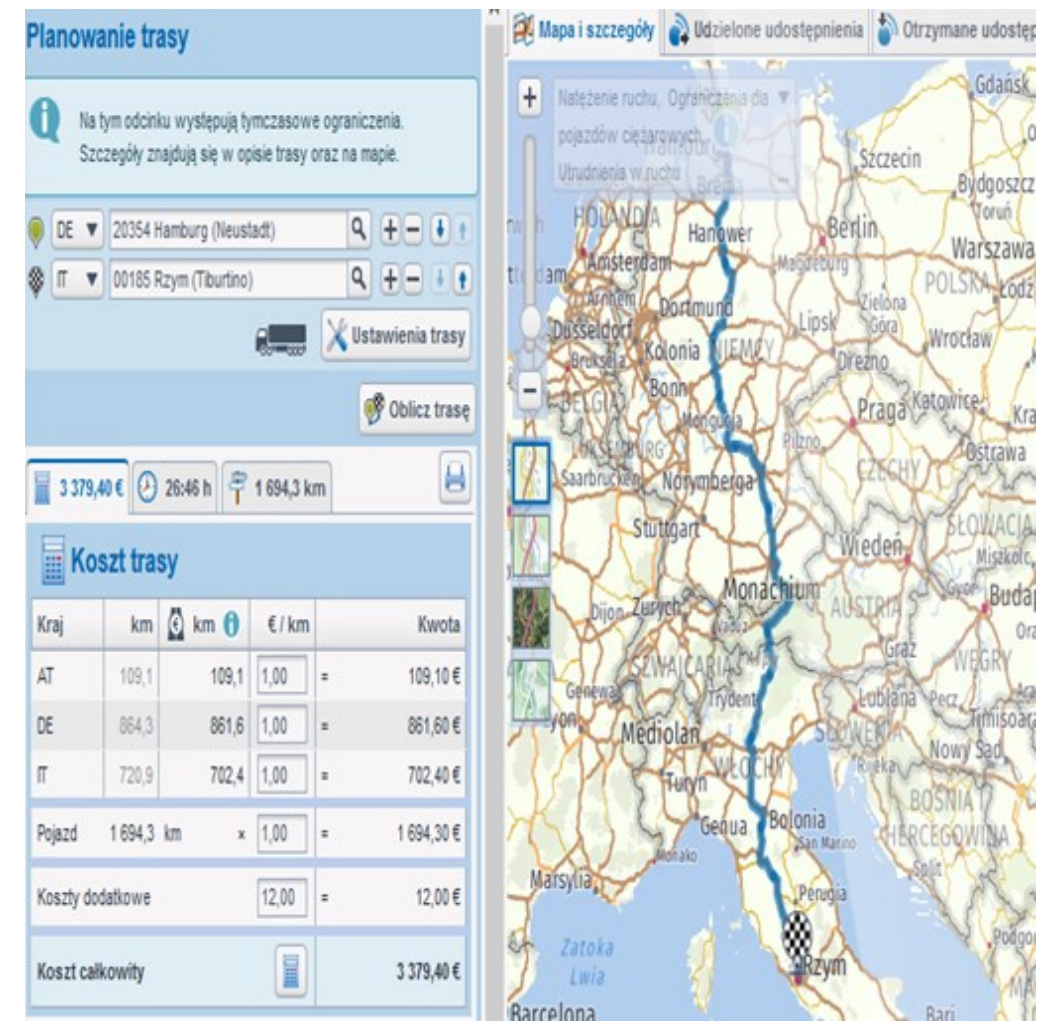

Fig. 4. An example of a calculated route on the TimoCom platform

Source: http://kcynia.info/kategoria/rondoinformator/

Elte GPSmart SMOK is a system for monitoring fleets of transport companies, which additionally enables the contact of the headquarters with the driver and direct transmission of the image from the recorder installed in the vehicle cabin to the receiver of the shipping center. A similarly operating telemetry system is software (INELO GBOX, Navifleet). The generated route using this application, called briefly GBOX is shown in Figure 5.

GBOX Assist is another example of a fleet management support tool. It has been supplemented with GPS navigation for trucks, which not only allows the driver to calculate the route, but also allows the destination point to be sent directly from the company. Thanks to this, it is possible to optimize travel routes [17].

NoVAB is a specialized software designed to calculate the axle load of a vehicle carrying oversized loads. The software accurately calculates the optimal position for the load in the vehicle combinations to be loaded. The program allows you to select a wide range of predefined vehicles such as box trucks, tractors, drawbar trailers, and specialized semi-trailers. The same applies to the choice of cargo, which is determined by parameters such as length, width, and weight. Once the load is defined, NoVAB calculates the axle load and the best possible load distribution. The optimal position of the load is also calculated to avoid exceeding the maximum axle load [10]. 


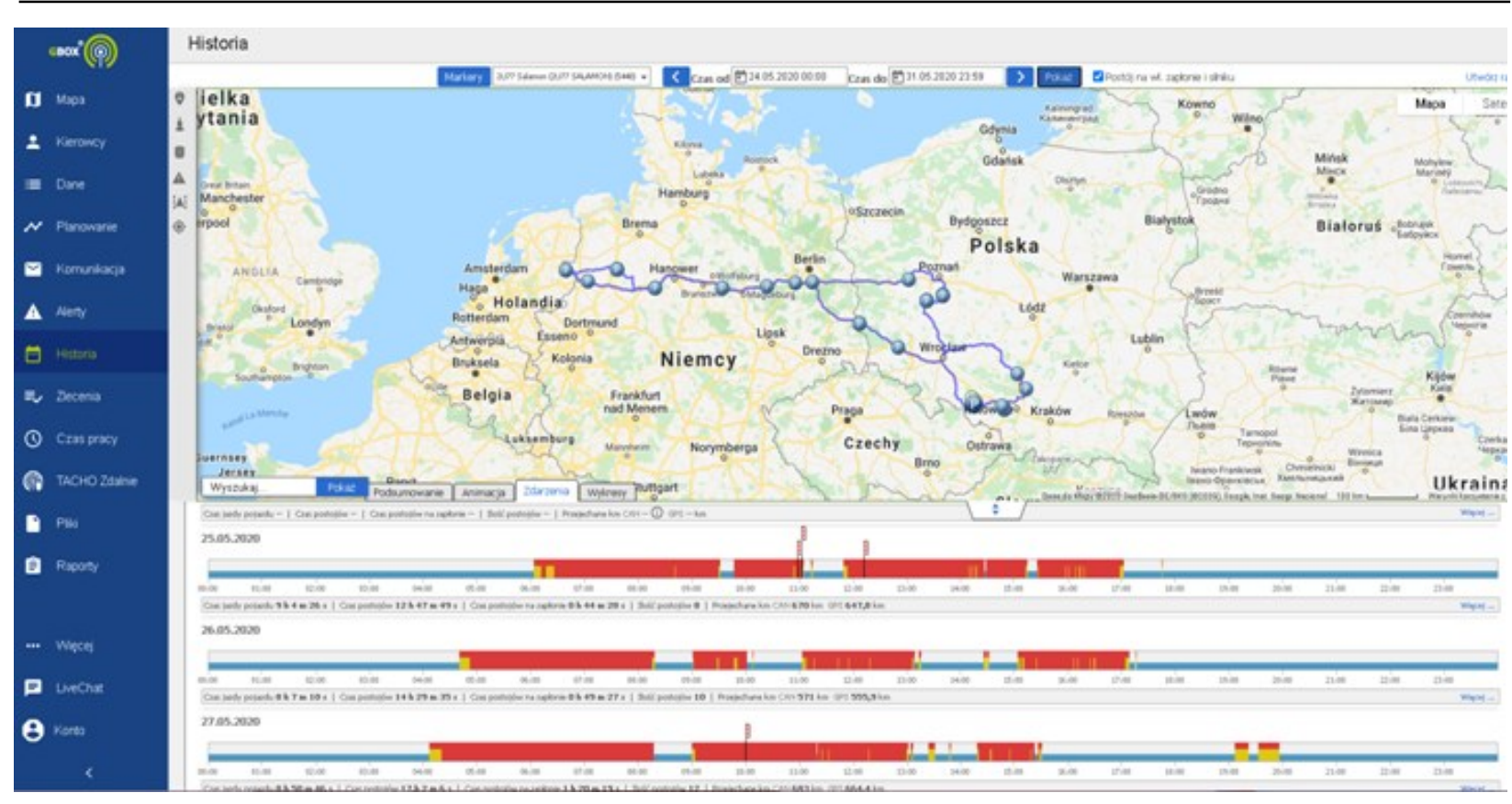

Fig. 5. Generated route using the GBOX program

Source: https://gbox.pl/pl/gbox-assist/

A similar program is the Goodloading system, which mainly helps in planning optimal cargo spaces, taking into account the axle load. The program saves frequently used loads as a specification of a given transport company and allows you to generate a loading project together with a visualization of the load on each axle of the vehicle (Fig. 6).

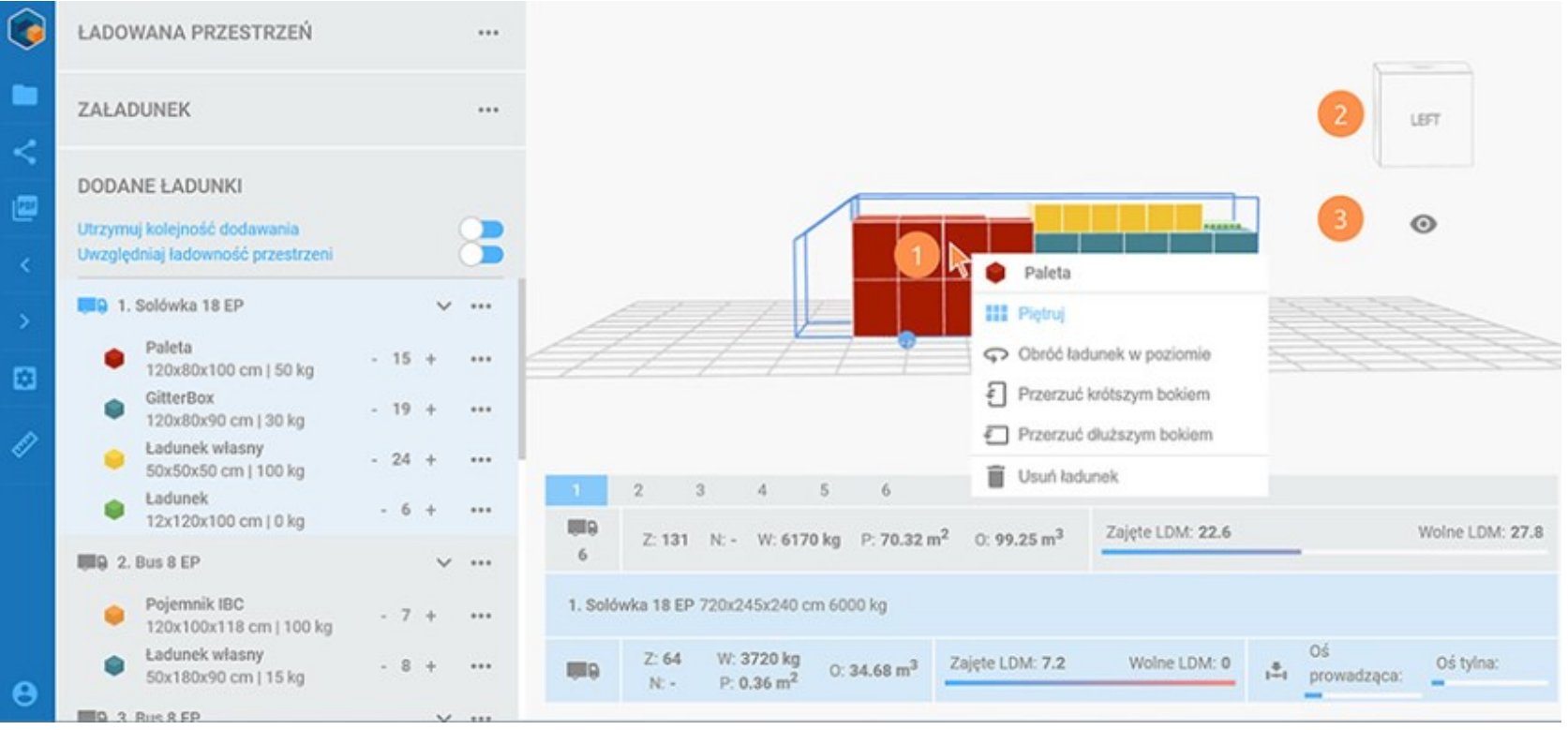

Fig. 6. Goodloading cargo planning

Source: based on: https: //www.goodloading.com/pl/instrukcja/

Easycargo, available on the Polish market, is also useful for oversized transport, which, like Goodloading, focuses on load distribution and axle load control. It is available in the form of traditional software and software adapted to remote work in the form of a smartphone application.

\section{The ability to better support forwarding logs}

A diagnostic survey conducted in an exemplary forwarding company Transport Towarowy Waldemar Kurspiot (TTWK) was to show the availability of individual systems supporting transport and indicate the possibilities of improving given software applications. The aforementioned enterprise has been operating continuously since 1992. From the very beginning, it has specialized in the transport of oversize goods in international and domestic traffic. Currently, the fleet consists of over 60 vehicles. The company deals with door-to- 
door logistics services, from door to door, related to the handling of oversized journeys, from obtaining relevant permits for travel, servicing of pilot vehicles, to the organization of disassembly of signs.

The main question to which the answer was given was the question about the demand for software in the TDL sectors specializing in the transport of long goods. The interview consisted of main questions supported by indepth and introductory questions. In the aforementioned company, the INELO - GBOX system is currently used. Currently, it is standard in transport companies. It works in online reading on Google maps in real mode, showing traffic, etc. Such a tool gives you the possibility to analyze routes and travel time in a short time. According to the representative of the company in which the interview was conducted, all vehicle tracking programs are useful, depending on what we are interested in. Therefore, a report is generated for each issue. We can check the vehicle's working time, fuel consumption analysis, and the amount of fuel remaining in the tank. We can generate such reports on a given day or an overall analysis covering the entire route. Reports are generated in a descriptive or graphic form. An important element is also the customer module in the form of a link, which allows you to view the vehicle in real-time. This allows, for example, quick and accurate preparation for the time of unloading, organization of employees, equipment, or cranes, the hiring of which is a considerable cost and there is no point in being ready all the time, generating unnecessary costs. Renting a crane cost about PLN 240 net for 1 hour, so providing the customer module allows you to save time and reduce costs.

The data module in the INELO - GBOX program, connected to the vehicle's on-board computer via the $\mathrm{CAN}$, enables the reading of the pressure e.g. on the saddle, which is an important aspect, because often bad distribution of pressure on the saddle, especially in the case of long logs, causes overloading of the towing axle. In addition, this program is affordable, with the ability to access via smartphone or web browser from anywhere in the world. The module has very minimal requirements. We only need a computer and internet access. It is distinguished by the transparency of the interface, negligible failure rate, online reading without delays, and the fact that it works on Google maps. Basic options are included in the subscription price. In addition, depending on the demand, it is possible to buy additional modules, including the latest one, which allows you to read the tachograph and read data when the vehicle is not on the database. However, it is worth supplementing the basic options with the driver's working time, the exact time of crossing the border, and the driver's rest time.

The interview shows that the abnormal transport sector still lacks one specific program that would be able to provide all relevant inquiries in one tool. Therefore, companies often use different programs at the same time. There is a company on the market that tries to build a unified, fully complete tool for logistics with its SOLOPLAN software (Fig. 7).

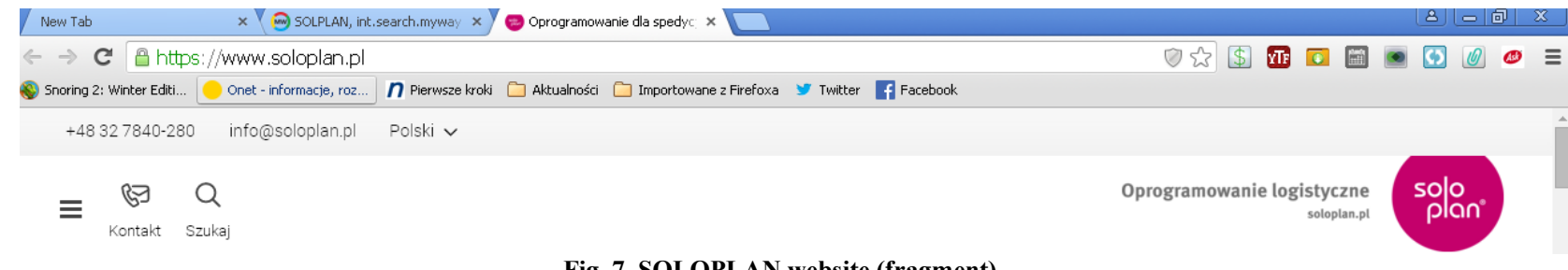

Source: https://www.soloplan.com/

Fig. 7. SOLOPLAN website (fragment)

The offered work support programs in the TDL sector may affect the quality and comfort of work, but they are not free systems. Certainly, the comfort of work is influenced by "clouds" with data and the Internet, especially the developing 5G network in Poland. In general, logistics software is currently the fastest growing IT service, so there is a good chance that one complete system will be available soon. Therefore, ordering the implementation of an adequate system supporting the forwarding of long transport would be an important step in the activities of the company presented earlier, which will result in the number and speed of orders being carried out over time. However, this requires a thorough pre-implementation analysis, paying particular attention to specialist needs. Such a package would include a number of improvements, especially in the area of a specific algorithm that will instantly associate a free vehicle with a load.

Currently, a travel permit is issued in paper form, but a lot of effort is required to obtain it. The driver must have the original permit while making the journey, but it is not the driver who receives it, but third parties who then have to pass this document on to him. It should be added that in the forwarding and long-term transport industry, digitization hardly occurs, and individual road authorities do not cooperate. Reconciliation of a given transport takes place traditionally using e-mails, faxes, which extends the time. In the Netherlands, on the other hand, there is an electronic route reconciliation system based on road data. Everything is done via the website. Operation is very simple: enter the dimensions of the vehicle, weight, place of loading and unloading. The system itself determines the available route for us. Local boards are digitally connected. There is also no problem with changing the registration number of the tractor and the trailer. This can be done even before the start of the route, as long as the new tractor technology corresponds to the one declared in the system. However, in Poland it is still impossible. So, if the tractor becomes immobilized, e.g. due to a breakdown, we must apply for a new permit. There is also no uniform road database. 
The road database operates in most Western European countries. Already at the stage of agreeing to the route, which is made via the website, we receive information about the width of the road, the height of the gauge, load capacity of bridge structures, radii of horizontal and vertical curves, which are important when planning long transport routes. Such a base is run by the road administrator. In the case of the Netherlands, it is RDW, i.e. the equivalent of the General Directorate for National Roads. The system itself determines the optimal route, taking into account the declared parameters and the condition of the infrastructure, along with possible difficulties such as road reconstruction. This is due to the cooperation of the road administrator with construction companies, which are obliged to provide all relevant parameters of the road geometry during its commissioning. Additionally, all temporary traffic restrictions are applied on an ongoing basis.

\section{Conclusions}

Regarding traffic disruptions, GDDKiA publishes on its website a list of planned (such as repairs) and unplanned difficulties, which is a list of ongoing road incidents. It does work, however, for typical road users. If something happens on the A4 motorway, which results in a detour, an appropriate message will be displayed on the website. The same applies to planned road upgrades, so you can be prepared for possible difficulties and set a new route. The information is provided with a password, e.g. the A-12 sign icon will inform us that the road is narrowed, but there is no information about how much the road has been narrowed on a given section. Thus, the functioning of the aforementioned solution introduced by GDDKiA still requires extension and improvement.

\section{References}

1. Chukurna, O., Pylchenko, A., Dobrovolskyi, V. (2019). Ecological Logistics: Problems of Formations of Green Supply Chain. Zeszyty naukowe, Katowice: Wyższa Szkoła Tehnichna w Katowicach. Issue 11. 103-118.

2. Filyppova, S., Bovnegra, L., Chukurna, O., Vudvud, O., Dobrovolskyi, V. (2021). Assessment of the Impact of Automatic Parking on Emissions of Harmful Substances in the Green Logistic System. In: Karabegović I. (eds) New Technologies, Development and Application IV. NT. Lecture Notes in Networks and Systems, vol. 233. Springer, Cham. Available at: https://doi.org/10.1007/978-3-030-75275-0 89

3. Havrylenko, N.V. (2013). Prohnozuvannia rozvytku rehioniv na pidstavi bahatofaktornykh modelei. Ekonomika. Finansy. Pravo. Shchomisiachnyi informatsiino-analitychnyi zhurnal (Kyiv), vol. 12(1), 19-22.

4. Jeden system dla całego procesu transportowego. Available at: https://cutt.ly/pYoYtRy.

5. Jóźwiak, Z. (2013). Techniczne i logistyczne aspekty transportu ładunków ponadnormatywnych, Wydawnictwo Uczelniane Wyższej Szkoły Gospodarki w Bydgoszczy, Bydgoszcz.

6. Marciniak-Neider, D., Neider, J. (2014). Podręcznik spedytora, op. cit.

7. Mendyk, E. (2002). Ekonomika i organizacja transportu, Wyższa Szkoła Logistyki, Poznań.

8. Nestorenko, T.P. (2007). Infrastruktura horoda v kontekste eho konkurentosposobnosti [City infrastructure in the context of its competitiveness]. Zb. nauk. prats (Mykolaiv), is. 59 Economic sciences, Petro Mohyla Black Sea State University, vol. 72, pp. 70-76. Available at: https://cutt.ly/zQEgQ3A

9. Nestorenko, T., Popova, Yu., Savchenko, L., Maksymov, S. (2020). Adaptation of Wilson's Model for International Trade. Journal of Modern Economic Research. Issue 1(4), 33-43. Available at: https://cutt.ly/fWfleLe

10. Nooteboom introduces NOVAB 3.0 Axle load calculation. Available at: https://cutt.ly/YYoYp76.

11. Ostenda, A., Nestorenko, T. (2018). Ekologiczne środki transportu a jakość życia mieszkańców aglomeracji górnośląskiej. Vzdelávanie a spoločnost’ III, Medzinárodný nekonferenčný zborník. Editorky: doc. RNDr. R. Bernátová, PhD., doc. T. Nestorenko. Slovensko: Prešovská univerzita v Prešove, 227-235. Available at: https://cutt.ly/5Wflwsa

12. Sosnowski, J., Nowakowski, Ł. (2018). Systemy elektroniczne w transporcie drogowym, op. cit

13. System zarządzania flotą transportową. Available at: https://cutt.ly/dYoYwI2.

14. Rozporządzenie Ministra Transportu, Budownictwa i Gospodarki Morskiej z dnia 23 maja 2012 r. w sprawie pilotowania pojazdów nienormatywnych.

15. Transport elementów siłowni wiatrowych. Available at: https://cutt.ly/6YoYuE6. is. $1,175-180$

16. Wornalkiewicz, W., Kravchyk, Yu., Kaplunovska, A. (2021). The oversized cargo forwarding: economic and legal aspects. № 5,

17. Zdalnie zczytywanie danych z karty kierowcy i tachografu. Available at: https://gbox.pl/pl/gbox-assist/

18. Zubro, T. (2014). Euroázijská ekonomická únia - niektoré aspekty integrácie. In Sociálno-ekonomická revue: vedecký časopis Fakulty sociálno-ekonomických vztahov Trenčianskej univerzity Alexandra Dubčeka v Trenčíne. Trenčín: Trenčianska univerzita Alexandra Dubčeka v Trenčíne. ISSN 1336-3727, 2014, roč. 12, č. 3, 28-36. Available at: ftp://193.87.31.84/0197064/Socialno_/ekonomicka_/ revue_volume_3_2014.pdf. 